$$
\begin{array}{r}
\text { ABORDAGEM DA PRÁT } \\
\text { COLECIONISTA ATRAVÉS D } \\
\text { CONJUNTO DE PEÇAS MARAJOAR } \\
\text { MUSEU NACIONAL DE ETNOL } \\
\text { EM LISBOA (PORTU }
\end{array}
$$




\section{ABORDAGEM DA PRÁTICA COLECIONISTA ATRAVÉS DE UM CONJUNTO DE PEÇAS MARAJOARA DO MUSEU NACIONAL DE ETNOLOGIA EM LISBOA (PORTUGAL)}

\section{J O A N N A TROU F F L A R D}




\title{
ABORDAGEM DA PRÁTICA COLECIONISTA ATRAVÉS DE UM CONJUNTO DE PEÇAS MARAJOARA DO MUSEU NACIONAL DE ETNOLOGIA EM LISBOA (PORTUGAL)
}

\section{Resumo}

O Museu Nacional de Etnologia em Lisboa tem no seu acervo várias peças marajoara provenientes de uma recolha encomendada pelo próprio Museu nos anos 60 do século XX, as quais se encontram atualmente expostas nas "Galerias da Amazônia". A expedição à ilha do Marajó foi realizada pelo colecionador e arqueólogo amador português Victor Bandeira, acompanhado por sua esposa Françoise Carel-Bandeira, tendo sido escavada uma necrópole da fase Marajoara situada no sítio d' "Os Camutins", na região do rio Anajás. Como objetivo principal deste trabalho, procurei entender as motivações que conduziram à escolha dos objetos trazidos para Portugal e que poderiam, segundo o protagonista da expedição, representar a cultura marajoara no museu português. Esta questão é investigada através do testemunho de Victor Bandeira. Segundo as informações reunidas, entende-se que na recolha abordada, a perspectiva colecionista ultrapassa a arqueológica. Isto permite-me refletir sobre o próprio ato de colecionar, assim como sobre a relação do colecionador com os objetos que reúne, dentro do domínio específico constituído pelos artefatos das culturas pré-colombianas.

Palavras-chave: cerâmica marajoara, Museu Nacional de Etnologia, colecionismo.

\section{APPROACH TO COLLECTING THROUGH A SET OF PIECES OF MARAJOARA CERAMICS FROM THE NATIONAL MUSEUM OF ETHNOLOGY IN LISBON (PORTUGAL)}

\begin{abstract}
The Nacional Museum of Ethnology, in Portugal, currently house several Marajoara pieces. These are exhinited at the "Galleries of Amazon", and were collect during the 1960's, on behalf of the Museum by the collector and amateur archaeologist Victor Bandeira and his wife Françoise Carel-Bandeira. The material was recovered from a Marajoara phase mound excavated at the site "Os Camutins", in Anajás River basin. This paper major objective is to understand the rationale behind the selection of the pieces which were brought to
\end{abstract}


Portugal, since they represent the expedition coordinator opinion on what was representative of the marajoara culture, and adequate for the Portuguese Museum. Based on an interview of Victor Bandeira, it became apparent that the material was selected from a "collection" perspective, rather than from an archaeological point of view. This situation lead us to think on the practice of collecting, as well as the relation between the collector and the objects collected within the specific context of pre-Columbian cultures.

Keywords: marajoara ceramics, Nacional Museum of Ethnology, collecting.

\section{ÉTUDE DU COLLECTIONISME À TRAVERS UN ENSEMBLE DE PIÈCES MARAJOARA DU MUSÉE NATIONAL D'ETHNOLOGIE À LISBONNE (PORTUGAL)}

\section{Résumé}

Le Musée National d'Ethnologie de Lisbonne possède une importante collection de pièces marajoara. Elles se trouvent exposées dans les "Galeries d'Amazonie" et ont été recueillies lors d'une commande faite par le propre Musée dans les années 60 du XXème siècle. L'expédition au Marajó a été réalisée par le collectionneur et archéologue amateur portugais Victor Bandeira, acompagné par son épouse Françoise Carel-Bandeira. Une nécropole de la phase Marajoara située dans le site archéologique "Les Camutins", dans la région du fleuve Anajás, a été fouillée. Le principal objectif de ce travail est de comprendre les motivations qui ont conduit aux choix des pièces recueillies qui, selon Victor Bandeira, seraient capables de représenter la culture marajoara au sein du Musée portugais. Cette idée se trouve développée à travers le témoignage de Victor Bandeira. À partir des informations réunies, nous comprenons que dans l'expédition que nous évoquons la portée collectioniste l'emporte sur l'archéologique. Ceci nous permet de réfléchir sur le propre acte de collectionner ainsi que sur la relation du collectionneur aux objets qu'il reunit, dans le domaine spécifique que constituent les pièces de cultures précolombiennes.

Mots-clés: marajoara, Musée National d'Ethnologie, collectionisme. 


\section{INTRODUÇÃO}

A coleção de artefatos marajoara do $\mathrm{Mu}-$ seu Nacional de Etnologia (MNE) em Lisboa constitui a maior do gênero em Portugal, sendo somente conhecida a existência de outra coleção, bem menor, no Museu Dr. Santos Rocha, em Figueira da Foz. O espólio em questão, recolhido em contexto funerário, é composto por 67 fragmentos de peças em bom estado de conservação e cerca de 200 fragmentos de diversas dimensões. Destacam-se a presença de tangas, muiraquitãs em cerâmica, machados líticos, vasilhas, estatuetas e urnas funerárias antropomórficas $^{1}$, tendo sido a análise arqueológica deste conjunto realizada no âmbito da minha dissertação de mestrado ${ }^{2}$; tratando-se de um estudo de arqueologia sobre artefatos ausentes de contextualização arqueológica e tendo sido possível contatar diretamente com o protagonista desta recolha, escolhi ampliar o meu trabalho realizando uma abordagem da coleção do $\mathrm{Mu}$ seu Nacional de Etnologia à luz da questão do colecionismo.

O que motivou primeiramente este trabalho foi minha curiosidade em conhecer a história da recolha dos artefatos trazidos do Marajó pelo colecionador Victor Bandeira para figurarem no Museu em Lisboa. Procurando entender, de certa forma, a relação que o colecionador tem com os objetos, proponho refletir sobre um tipo específico de coleção designada de "arte primitiva". Sabe-se que não é raro encontrar, durante trabalhos de campo na região do Baixo Amazonas, moradores em comunidades assentadas sobre sítios arqueológicos que juntam cuidadosamente fragmentos de peças arqueológicas (cerâmicas e líticos; e por vezes algumas formas naturais invulgares em laterita) encontrados ao longo do tempo e realizados por antigas comunidades indígenas. Embora as "coleções domésticas" assim constituídas possam oferecer um estudo $\mathrm{em} \mathrm{si}^{3}$, neste trabalho escolhi analisar o discurso de ditos grandes colecionadores, ou seja, indivíduos conhecidos internacionalmente por suas coleções de objetos pré-colombianos. Enfim, pareceu-me essencial incluir ao estudo o testemunho de Victor Bandeira, que me permite olhar para o conjunto de peças do MNE do ponto de vista de uma coleção constituída com os critérios específicos do colecionador, afastando-a da recolha arqueológica sistemática.

\section{A COLEÇÃO MARAJOARA DO MUSEU NACIONAL DE ETNOLOGIA}

O Museu Nacional de Etnologia de Lisboa reúne um dos maiores conjuntos de objetos realizados por ameríndios brasileiros em Portugal. A coleção de peças recolhidas por Victor Bandeira e Françoise Carel-Bandeira no Brasil durante a década de 60 do século XX é constituída por 738 objetos, na sua totalidade depositados naquela instituição, conjunto que inclui os espólios provenientes da recolha realizada pelo casal numa necrópole da região do rio Anajás $^{4}$, na ilha do Marajó. Entre estas peças, na maioria cerâmicas, destaca-se a presença de grandes urnas funerárias, ou igaçabas ${ }^{5}$, que teriam sido utilizadas em sepultamentos secundários, assim como uma série de objetos identificados no interior das mesmas. Todo este conjunto artefatual pertence à "fase 
marajoara" e à tipologia cerâmica correspondente, da tradição policrômica da Amazônia.

Victor Bandeira, protagonista da constituição desta coleção, pode ser descrito como um viajante, colecionador e antiquário com grande interesse por culturas e objetos de outros continentes. Numa entrevista realizada em 2000 para a revista Ícon, descreve como iniciou sua atividade:

Desde minido que gostava de objectos de arte, e um dia tive a possibilidade de fazer uma sociedade com dois indivíduos, abrir uma casa de antiguidades e fiquei todo contente, comecei a comprar coisas e a vender, foi por volta dos meus 25 anos. Cheguei à conclusão de que gostava era daqueles objectos que se costumam chamar de arte primitiva, e de arte popular e de arqueologia, e não havia especialistas em Portugal (Pratas 2000: 37).

Realço o fato de Victor Bandeira ter sido um precursor em Portugal na aquisição, recolha e venda de objetos provenientes das denominadas "culturas exóticas". No início adquiria os objetos sobretudo através de antiquários e de casas leiloeiras, e quando conseguiu juntar uma significativa soma de dinheiro foi para a África. Neste contexto, entende-se que constituiu coleções com o objetivo de as vender, tendo sido portanto também um comerciante. Sua motivação foi a de adquirir, através da revenda dos objetos, o financiamento suficiente para realizar suas inúmeras viagens. Assim, a colaboração com o Museu Nacional de Etnologia correspondeu para Victor Bandeira a uma situação cômoda com a garantia de que teria um cliente fiel. Desta forma, concluo que, ao contrário da ideia do colecionador que forma uma coleção ao longo do tempo para seu usufruto pessoal, Victor Bandeira foi antes de mais nada um antiquário. No entanto, admirador permanente dos objetos das várias culturas que ia descobrindo, não hesitava em visitar o Museu para poder rever as coleções. Além disso, desenvolveu uma amizade profunda com os funcionários da instituição. Passo a citar o antiquário: "E não podendo ficar com todos os objetos de que gostava, vendendo ao museu podia vê-los quando quisesse. Continuavam a ser meus de certa maneira" (Pratas 2000: 38). Foi nesta ótica que Victor Bandeira e Françoise Carel-Bandeira, então sua esposa, foram encarregados da recolha de objetos ameríndios na Amazônia.

A expedição de Victor Bandeira e Françoise Carel-Bandeira foi incentivada pelo diretor do então Museu de Etnologia do Ultramar, António Jorge Dias (19071973), e insere-se na continuação de viagens realizadas com a finalidade de efetuar recolhas etnográficas na África, Ásia e América. Desta forma, não deixa de suscitar certas reminiscências pós-coloniais. O primeiro contato entre o antropólogo e Victor Bandeira ocorreu enquanto decorria a exposição da sua coleção de objetos africanos, na inauguração do $\mathrm{Mu}-$ seu da Escola Superior de Belas Artes no Porto. É de se destacar que, durante as suas viagens, Victor Bandeira e Françoise Carel-Bandeira não se limitavam somente às recolhas etnográficas, mas valorizavam igualmente a experiência vivencial com as populações contatadas.

Sabe-se, por exemplo, que na ocasião da expedição ao Xingu, na Amazônia 
brasileira, Victor Bandeira e Françoise Carel-Bandeira permaneceram durante um ano em uma aldeia dos kamaiurá ${ }^{7}$. Através da recomendação do Centro de Estudos de Antropologia Cultural da Junta de Investigações do Ultramar, Victor Bandeira e Françoise CarelBandeira entraram em contato com os Serviços Culturais da Embaixada do Brasil a fim de realizarem a expedição, e foi durante os anos 1964/65 que constituíram a coleção encomendada pelo $\mathrm{Mu}$ seu. O conjunto de peças recolhidas foi adquirido pelo Ministério do Ultramar em 1969, com a ajuda da Fundação Calouste Gulbenkian, da Fundação da Casa de Bragança e de alguns particulares (Oliveira 1972). O Museu foi comprando peças do antiquário durante anos, muito embora os gastos com as viagens e as compras dos objetos tenham sido sempre custeados pelo próprio Victor Bandeira. Assim, parece ter-se constituído um acordo para benefício de cada uma das partes: para o $\mathrm{Mu}-$ seu, na aquisição de artefatos inéditos; para Victor Bandeira, na revenda das suas coleções.

As peças encomendadas pelo Museu foram recolhidas através de uma escavação na qual o registro arqueológico foi quase nulo. Foi realizada por pessoas estranhas à arqueologia científica e as informações que chegaram até nós, das quais não faz parte qualquer registro estratigráfico, não permitem contextualizar o conjunto. A escavação ocorreu no teso Camutins, situado na parte central da ilha. O teso se localiza junto ao igarapé dos Camutins, afluente do rio Anajás e pertence ao sítio d' "Os Camutins", composto por um conjunto de 34 tesos (Schaan 2004), um dos maiores e mais conhecidos de toda a ilha do Marajó.

Os tesos encontram-se divididos em três categorias, distribuídos espacialmente ao longo do rio Camutins. No curso inferior identificaram-se quatro, área onde parece ter sido organizado o núcleo cerimonial e político; no médio curso do rio reconheceram-se 15 , aos quais estararia associada a população comum; finalmente no curso superior terse-ão encontrado outros 15 (Schaan 2006). A densidade populacional deste cacicado foi estimada em cerca de 2.000 pessoas (Schaan 2004: 395). O teso de Camutins, de onde provem a recolha realizada por Victor Bandeira e Françoise Carel-Bandeira é o maior do grupo e constitui assim um efetivo testemunho da organização de rituais funerários pela elite marajoara ${ }^{8}$.

Apesar de a expedição de Victor Bandeira e Françoise Carel-Bandeira corresponder sobretudo a uma recolha carente de registro arqueológico, o casal teve a preocupação de salvar alguns dados relativos ao posicionamento dos objetos encontrados. Registraram o fato de as urnas funerárias se encontrarem enterradas a poucos centímetros de profundidade, assim como informações sobre o posicionamento dos objetos, eventualmente reconhecidos no seu interior ou enterrados à sua volta, na necrópole (Figuras $1,2,3$ e 4). 

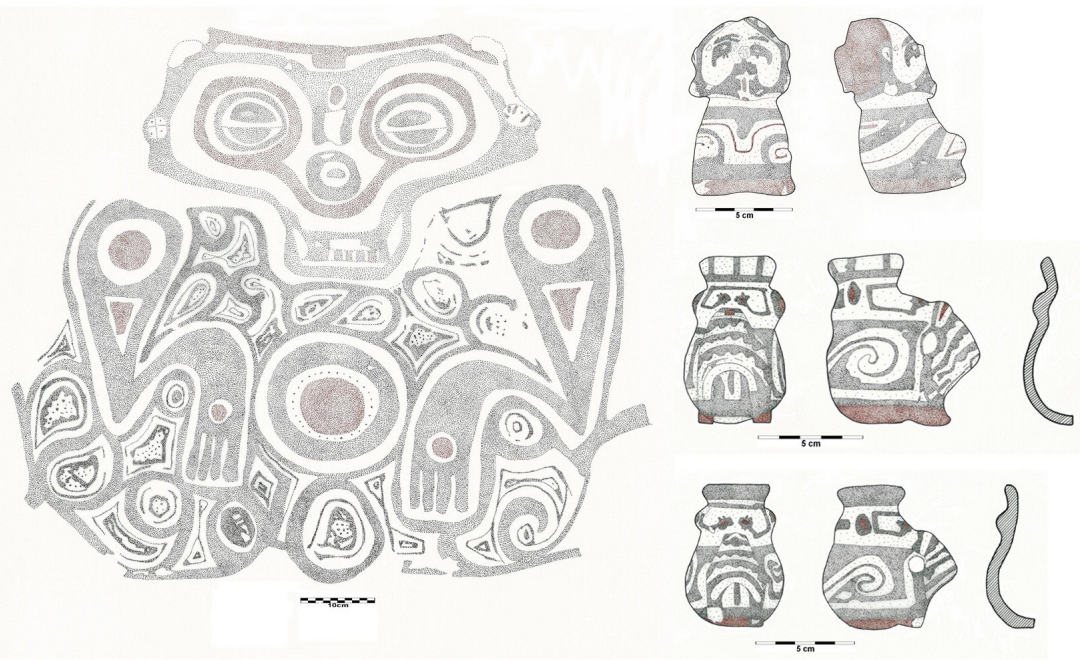

Figura 1- Urna funerária Joanes pintado 9 (AN.372) dentro da qual se encontraram uma estatueta antropomórfica Joanes pintado (AN.390) e um par de vasos zoomórficos Joanes pintado (AN.388 e AN.389).
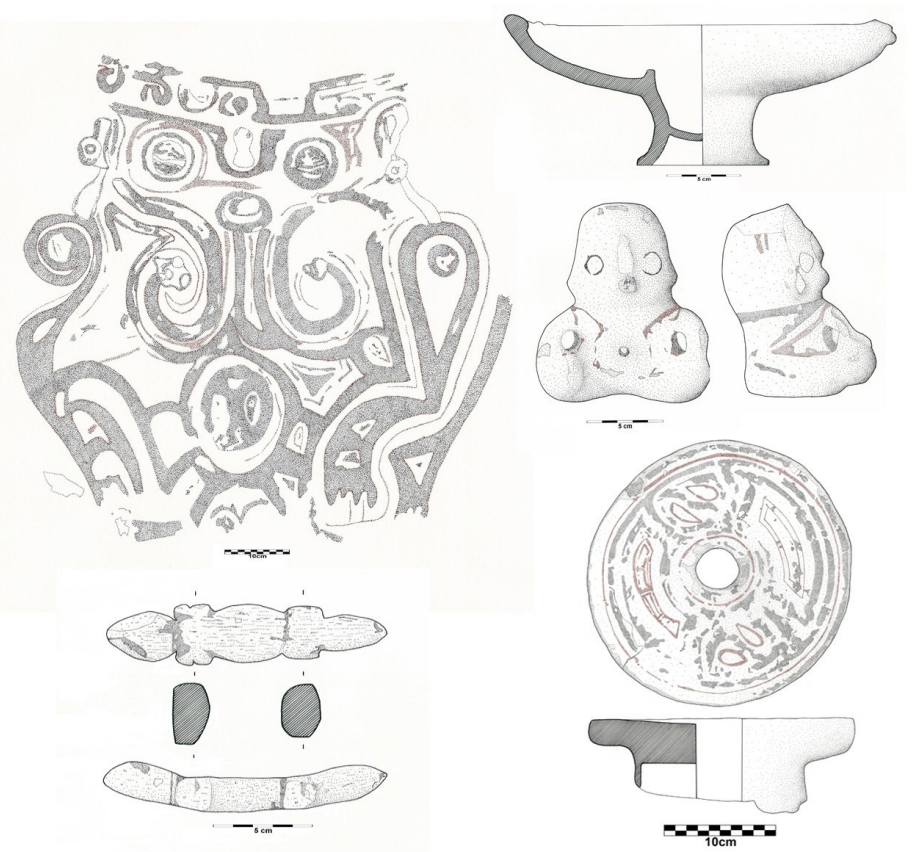

Figura 2 - Urna funerária Joanes pintado (AN.375). No seu interior reconheceram-se uma estatueta zoomórfica em osso (AN.369), uma vasilha com pedestal Carmelo vermelho ${ }^{10}$ (AN.395) e uma estatueta chocalho Joanes pintado (AN.381). A urna estava junto a um tamborete Joanes pintado (AN.385). 


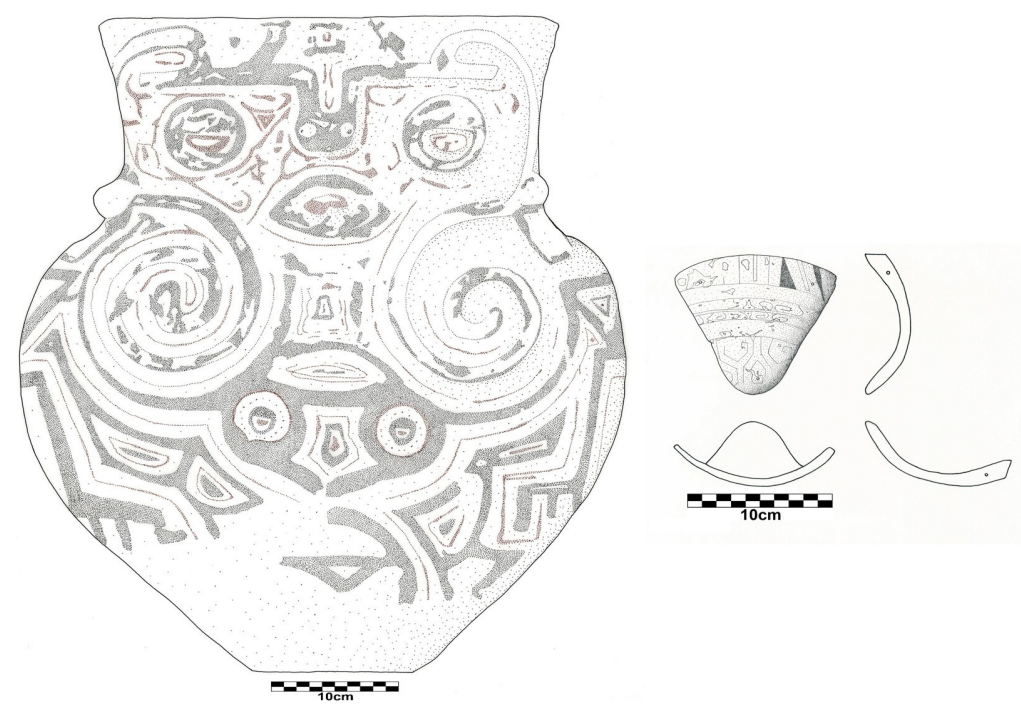

Figura 3- Urna funerária Joanes pintado (AN.374) descoberta com uma tanga Joanes pintado no seu interior (AN.386).

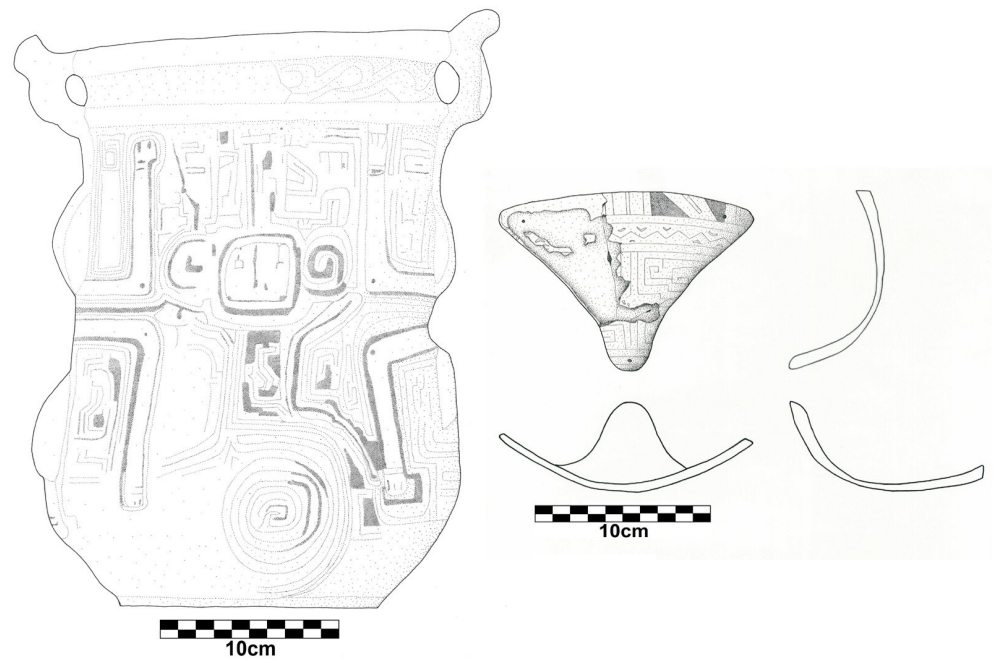

Figura 4- Urna funerária Arari exciso vermelho ${ }^{11}$ (AN.380) e tanga Joanes pintado que estava no seu interior (AN.387).

As peças recolhidas durante a expedição de Victor Bandeira e Françoise CarelBandeira no Marajó estão atualmente expostas nas reservas musealizadas do $\mathrm{Mu}-$ seu Nacional de Etnologia, as denominadas
"Galerias da Amazônia". Este conjunto não constitui a única coleção brasileira recolhida pelo casal, pois existem vários conjuntos etnográficos e outras recolhas de objetos arqueológicos trazidos da Améri- 
ca do Sul. Valerá a pena citar, como exemplo, o conjunto de cerâmicas précolombianas do Peru.

A construção deste espaço museológico teve início em 1998 e foi inaugurado no dia 10 de janeiro de 2006, sendo constituído por duas mil peças e destacandose duas grandes coleções: aquela proveniente da recolha aqui em estudo e a da colheita organizada por Neto junto aos wauja do alto rio Xingu, no ano $2000^{12}$. Existem, para além destes conjuntos, algumas coleções menores e diversos objetos isolados.

\section{- COLECIONISMO E OS VESTÍGIOS ARQUEOLÓGICOS}

De várias obras sobre a temática do colecionismo, considero que o trabalho realizado por Derlon e Jeudy-Bellini (2008) se destaca pela originalidade. De fato, é composto por uma série de "confissões" de colecionadores analisadas com grande pertinência. No presente estudo assumo certos princípios dos autores em três análises distintas: na introdução à questão do colecionismo, nos discursos feitos por grandes colecionadores de peças americanas, e na entrevista que realizei com Victor Bandeira.

Uma das primeiras ideias que me surge, enquanto arqueóloga a estudar peças recolhidas no âmbito da constituição de uma coleção, é caracterizar estas duas entidades, ou seja, o colecionador e o arqueólogo. Segundo Schnapp,

L'antiquaire est friand de tout ce qui est ancien, il classe les objets et les monuments suivant des règles aussi anciennes que mal définies: per genus proximum et differentiam specificam ("par le type le plus proche et la différence la plus avérée"); l'archéologue veut constituer le monde des objets en systèmes, it élargit le concept de monuments (qui ont été fabriqués ou édifiés pour monere, "avertir") à celui des traces, restes infimes parfois qui sont le résultat de l'activité inconsciente des bommes du passe. ${ }^{13}$ (Schnapp 2009: 12).

Decidi analisar o ponto de vista do colecionador, associado por Schnapp ao antiquário, destacando, porém, aquilo que o aproxima da disciplina arqueológica: o fascínio pelo passado. Considerei que a posição do colecionador se identifica com uma atividade mais individualista, associada, numa perspectiva inconsciente, à procura das origens. O trabalho do arqueólogo possui uma dimensão mais universal, pois estuda o homem através de sua cultura material com um objetivo claramente histórico. Do ponto de vista metodológico, lembro que o colecionador privilegia os resultados, sendo o método somente uma maneira de chegar à aquisição dos objetos, enquanto a investigação do arqueólogo tem uma vocação científica patente. Para evitar generalidades sobre este tema extenso, decidi centrar o interesse na questão da coleção de objetos relacionados com culturas não-europeias, correspondendo geralmente ao adjetivo "exótico" ou à designação genérica de "arte primitiva"14. Junto aos atributos precedentes objetos que poderiam entrar em classificações diversas, como "arte", "arqueologia", "etnologia" ou "etnografia", e escolhi elaborar a análise em torno do que penso possuírem em comum. Notei que os objetos qualificados desta forma costumam ser associados a uma temporalidade passada 
e anterior, isto apesar da sua confecção poder ser atual. Escreve Baudrillard:

Os objectos exóticos: o deslocamento e a diferença de latitude equivalem seja como forpara o homem moderno a um mergulho no passado. Objectos feitos a mão, indígenas, bagatelas de todos os países, é menos a multiplicidade pitoresca que fascina do que a anterioridade das formas e dos modos de fabricação, a alusão a um mundo anterior, sempre alternado por aquele da infância e dos seus jogos (Baudrillard 2004: 83).

Ou seja, estes artefatos são vistos como pertencendo a um tempo passado, dada a técnica associada à sua confecção, por força da distância geográfica do lugar onde foram produzidos e também por sua conotação com as esferas ritual, religiosa ou mágica. Note-se que este último elemento não é minimizado pelos colecionadores, pelo contrário: a presença da mística e do irracional atua no sentido de uma aproximação fusional entre a pessoa e o objeto. A esta percepção de temporalidade através do objeto colecionado acrescento o fator da funcionalidade, relacionado com duas ideias: a funcionalidade efetiva no passado e a sua ausência no presente. Neste sentido, uma das condições do objeto colecionado seria o seu uso anterior, que lhe consagraria realidade, verdade e autenticidade. Este seria o fator fundamental que lhe permitiria ser mediador temporal entre as pessoas do passado e do presente. Ainda segundo Baudrillard, "O objecto mitológico, de funcionalidade minimal e de significação maximal, refere-se à ancestralidade, ou mesmo à anterioridade absoluta da natureza." (Baudrillard 2004: 89). Refiro como exemplo ilustrativo desta ideia o exemplo do intelectual alemão Benjamin, fervoroso colecionador de livros, que afirma como característica dos colecionadores de livros o fato deles precisamente não lerem (Benjamin 2000: 45). Pomian também observa neste aspecto uma relação antagônica estabelecida entre o significado do objeto e a sua utilidade. Assim, a utilidade atribuída ao objeto seria proporcionalmente inferior ao significado dado ao mesmo. Os leilões seriam então considerados lugares privilegiados desta transformação: da utilidade ao significado (Pomian 1987: 44). A ausência do uso seria uma forma de permitir ao colecionador que se concentrasse exclusivamente sobre a origem e a história do objeto em vez de explorar a sua funcionalidade (Allen in Benjamin 2000: 23).

Sendo este estudo baseado sobre a análise de um conjunto artefatual de caráter funerário, aproveito para abrir um parêntesis a fim de caracterizar este tipo específico de objetos. De fato, supõe-se que as oferendas que se encontram depositadas em contextos funerários como necrópoles deveriam ser vistas pelos defuntos, porém jamais utilizadas. Assim pode-se pensar que, de certa forma, os objetos funerários estariam duplamente ausentes do circuito funcional: não seriam confeccionados para serem utilizados e continuariam sem o ser quando da sua entrada no interior do universo colecionista (Pomian 1987: 22).

Outra ideia que os colecionadores associam ao objeto de "arte primitiva" é a da relação que o conhecimento pode ter com a emoção, num sentido por vezes antagônico. Note-se que certos 
colecionadores têm prazer em cultivar o maior grau de mistério possível em torno do objeto colecionado, ou seja, concebem o saber como um obstáculo à emoção estética e ao exercício do imaginário (refiro, como exemplo recorrente, o desconhecimento do autor da obra). O sentimento de posse do objeto desenvolvido pelo colecionador será facilitado pela ausência de informações sobre o mesmo. A ignorância em relação à história da peça, ao autor que a confeccionou ou ao seu país de origem será precisamente uma das coisas que permite a apropriação desta criação pelo colecionador. Note-se que a emoção estética provocada pelos objetos se relaciona também com percepções temporais, como afirma um colecionador: "Ce n'est pas parce qu'il est beau que l'objet fait rêver et voir le monde autrement; c'est parce qu il fait rêver et voir le monde autrement qu'il est beau."15 (Derlon \& Jeudy-Ballini 2008: 81). Segundo Jean Baudrillard, “...todo objecto antigo é belo simplesmente porque sobreviveu e devido a isso torna-se o signo de uma vida anterior." (Baudrillard 2004: 91). O objeto torna-se um testemunho de um tempo sentido como anacrônico.

Ainda numa tentativa de análise da questão temporal associada ao objeto de "arte primitiva", sublinho a ideia de posteridade do objeto em relação ao seu colecionador. Seja por sua circulação entre as mãos de diversos colecionadores, ou por sua inserção em alguma instituição museológica, o objeto perpetua a memória do colecionador através do tempo e, por extensão, depois da morte. "O homem que colecciona está morto, mas sobrevive literalmente em uma colecção que, a partir desta vida, repete-o indefinidamente para além da morte, ao integrar a própria morte na série e no ciclo." (Baudrillard 2004: 105) Noutro sentido, valerá a pena abordar a questão da identificação substancial entre pessoa e objeto. Cito, a propósito, um colecionador que na evocação de um objeto afirma: "Parfois, je finis par l'englober et je le regarde comme témoignage archéologique de moi-même."16 (Derlon \& Jeudy-Ballini 2008: 190). A encarnação extrema desta ideia pode ser vista no fato de certos colecionadores terem o desejo de que suas cinzas funerárias venham a permanecer num objeto da sua própria coleção ${ }^{17}$.

Assim, esta corrente analítica que parte da designação bastante eloquente de "arte primitiva" e me conduz até certas questões existenciais, permite realizar uma reflexão sobre a relação dos objetos colecionados e dos colecionadores com o tempo. Lembro que esses objetos podem tanto pertencer à arqueologia como à etnografia, sendo o seu tempo real relativo perante o tempo que simbolizam.

\section{COLECIONADORES DE PEÇAS AMERICANAS}

Depois de tentar encontrar especificidades na coleção de objetos de "arte primitiva", meu objetivo será refletir sobre a originalidade das coleções de objetos pré-colombianos, assim como evocar a dicotomia existente entre colecionadores e investigadores e os termos "estética" e "conhecimento" na 
sua relação diferenciada com os objetos. Decidi destacar alguns protagonistas de grandes coleções americanas que também possuem objetos da Amazônia, aludir à história das suas coleções e analisar o discurso que têm sobre a sua paixão. A minha fonte principal é constituída por discursos dos próprios colecionadores no âmbito de grandes exposições internacionais que contaram com as suas peças ou presentes em outro tipos de entrevistas.

Decidi desenvolver minha reflexão a partir dos testemunhos de dois grandes colecionadores de peças americanas, Dora Janssen e Jean-Paul Barbier-Mueller, e do etnólogo, grande admirador de "arte primitiva”, Claude Lévi-Strauss (19082009). A colecionadora belga Dora Janssen possui um conjunto de peças da América pré-colombiana (incluindo peças da Amazônia pré-colonial) composto por 350 objetos. A coleção do suíço Jean-Paul Barbier-Mueller é composta pela herança da coleção de Josef Mueller (1887-1977), tendo sido algumas peças revendidas (dois terços das secções africanas e da Oceania, algumas peças pré-colombianas e de arqueologia mediterrânea) e outras adquiridas segundo a vontade de Jean-Paul BarbierMueller, expressa nos termos seguintes: "Je voulais constituer des ensembles cohérents de certaines régions ou centres de style." ${ }^{\prime 18}$ (Newton et al. 1995: 14). As peças de Jean-Paul Barbier-Mueller acham-se repartidas entre dois museus, um deles em Genebra e outro em Barcelona, dedicado especialmente às culturas da América pré-colombiana. A coleção americana é composta por cen- tenas de objetos, dos quais o colecionador destaca "une réunion inhabituelle de céramiques de l'île brésilienne de Marajó."19 (Barbier-Mueller 1987: 29). Por fim, evoco o interesse de Claude Lévi-Strauss por "arte primitiva", bem como a constituição de coleções que realizou para museus brasileiros e franceses, resultantes das duas expedições ao Brasil que efetuou com Dina LéviStrauss, nos anos 1930, a primeira pelo Brasil central entre os anos 1935-1936 e a segunda pelo Centro e Norte do país, entre os anos 1938-1939.

Destaque-se a diferença que existe entre a constituição dessas coleções: Dora Janssen e Jean-Paul Barbier-Mueller obtiveram os objetos por intermédio de antiquários ou de casas de leilões e privilegiaram a percepção estética do objeto nas suas escolhas e na visão que têm sobre os mesmos. Já Claude Lévi-Strauss, enquanto etnólogo, teve a oportunidade de fazer as suas próprias recolhas, com objetivo rigorosamente científico, atribuindo ao objeto um valor que é sobretudo de testemunho histórico. Neste trabalho, não será desenvolvido o problema da dicotomia entre coleções privadas e museológicas, nem a controvérsia relativa à presença de peças estrangeiras recolhidas em contextos problemáticos ${ }^{20}$.

Interessa-me, sim, a visão dos colecionadores sobre as suas peças, para tentar destacar algumas especificidades da coleção de arte pré-colombiana. É interessante mencionar os critérios que a colecionadora Dora Janssen adota na escolha das suas peças, privilegiando os aspectos estéticos e emocionais ("sur 
des bases esthétiques, sur des coups de coeur" $\left.{ }^{21}\right)$. Sua coleção foi iniciada na altura de uma viagem à Colômbia, onde Dora Janssen adquiriu um colar Chimu em ouro. ${ }^{22}$ Num primeiro momento, a colecionadora privilegiou objetos em ouro e foi progressivamente adquirindo um conhecimento mais aprofundado sobre as culturas pré-colombianas ("J'ai accumulé plus de 500 ouvrages sur l'art précolombien"23). Interessa-me particularmente o modo como qualifica este tipo de objetos na sua especificidade: "Alors que chez les Précolombiens, si les lignes sont moins pures et s'il peut y avoir aussi de très vilaines choses, il y a tant d'expression et d'étrangeté dans cet art qui réalise la symbiose avec la nature. On y trouve une religiosité. Les objets sculptés sont liés à la nature, au soleil, au jaguar." ${ }^{\text {"24; }}$ "Elles ont une autre dimension occulte. Pour moi, elle recèle des mystères, ceux des peuples qui vivaient en symbiose, avec la nature. Elles m'ont invitée à l'art de comtempler et de rêver." "25 Sobressaem destas citações duas ideias que me parecem particularmente interessantes. Do ponto de vista estético, apesar de essas peças não entrarem num padrão de perfeição que poderia ser considerado como ocidental, possuem qualquer coisa a mais que as diferencia das outras. Esta ideia está relacionada com o caráter irracional atribuído a esses objetos no sentido que já referi, de estímulo ao imaginário da pessoa que os possui. Outra ideia seria a proximidade e quase fusão desses objetos e das populações que os criaram com a natureza. Estou ciente da importância iconográfica de elementos ligados à natureza nos objetos ameríndios ainda que, a meu ver, a coleciona- dora revele alguns estereótipos ligados a uma certa percepção das culturas sul-americanas. Lembro que, até hoje, o modo de vida dos ameríndios é considerado harmonioso com o meio natural, certas vezes numa visão bastante idealizada. Todavia, a visão da floresta amazônica como paraíso verde virgem vem sendo contradita pelos estudos arqueológicos que testemunham uma ocupação antiga deste meio ambiente, que terá sido manipulado e, de certa forma, construído por seus habitantes. Outras vezes, são vistos como raros testemunhos de uma humanidade perdida no meio de uma imensidão natural hostil. Lembro que esta ideia do mundo ameríndio mais próximo da natureza do que da cultura constitui um preconceito tanto da visão europeia como da americana. ${ }^{26}$

Jean-Paul Barbier-Mueller refere uma ideia, inspirada em Charles Ratton, sobre um critério de escolha para a constituição de uma coleção: 'J'étais aveuglé par la vérité, par une vision: celle d'une collection formée "d'objets de rêve". ${ }^{27}$ (Barbier-Mueller \& Enthoven 2003: 8). Pela analogia com o sonho, este comentário acentua novamente a ideia do objeto de "arte primitiva" situado e sentido pelo colecionador como fora de qualquer temporalidade. Sempre em relação ao tempo, outra reflexão do autor evoca a noção de eternidade da coleção que preserva a memória do colecionador: "Seules les oeuvres sont importantes, qui restent et voient passer les collectionneurs." 28 (Barbier-Mueller \& Enthoven 2003: 7). Analiso a sua percepção sobre as peças amazônicas: "A cerâmica amazônica me fascina por 
ser arte quase em estado puro. [...] Mas é uma arte que espanta, basta ver as obras, o equilibrio estético, a riqueza de detalhes, o refinamento da ornamentação, a intenção de retratar o ser humano em objetos do cotidiano."29 (Sukman 2002). Desta descrição, sobressai a percepção dos objetos dessas culturas enquanto originais, no sentido de inatos e primitivos. Sobressai a enumeração de qualidades estéticas próximas da perfeição que reabilita os povos da Amazônia pré-colonial, numa escala próxima das civilizações americanas amplamente reconhecidas (por exemplo, a Inca). Refira-se a peça americana predileta do colecionador ${ }^{30}$ :

É uma urna antropomórfica da Baixa Amazônia, feita por volta do ano 1000, que retrata um homem sentado e enfeitado por desenhos geométricos perfeitos, que lembra as pinturas de corpo dos indios amazônicos. Essa pode ser considerada como uma das mais impressionantes criaçôes plásticas legadas pelos antigos indios da América à Humanidade."(Sukman 2002).

Verifica-se que além das qualidades estéticas atribuídas ao objeto este é descrito como se fosse dotado de trans-historicidade e de trans-culturalidade. Assim, através da coleção do Museu de Barcelona, destaca-se a prioridade claramente estética que preside à constituição destas coleções. Segundo a diretora deste $\mathrm{Mu}$ seu, "They have created a collection devoid of any ethnographic bias; it is carefully composed inventory of America's past, quite remarkable for the aesthetic quality and originality of its objects." ${ }^{\text {"31 }}$ (Casas 2004: 96). Assim, a constituição desta coleção evoca um discurso claramente artístico, não sendo prioritária a aquisição de conhecimentos objetivos so- bre a vida das populações da Amazônia antiga através da sua cultura material. Aliás, a questão estética está de tal forma presente no discurso do colecionador que este afirma: "Créer une œuvre faite des œuvres d'autrui, puisque je ne possedais aucun des dons comblant les véritables créateurs." ${ }^{32}$ (Barbier-Mueller \& Enthoven 2003). Compreende-se então a visão que tem da sua coleção como obra de arte em si, ilustração máxima de uma percepção exclusivamente estética dos objetos. Talvez seja outra das particularidades do colecionador, que além de salvar o objeto antigo do esquecimento, também afirma o seu direito à criação (Allen in Benjamin 2000: 24).

Por fim, valerá a pena refletir sobre a relação de Claude Lévi-Strauss com a "arte primitiva". Sabe-se que colecionava estes objetos, que já o fascinavam antes de se tornar etnólogo, e que nunca deixou de os admirar, também por suas qualidades artísticas. No que se refere às suas recolhas no Brasil, sabe-se que as peças das duas expedições que realizou foram repartidas entre o Brasil e a França, estando hoje no Museu de Arqueologia e Etnologia da Universidade de São Paulo e no Musée du Quai Branly, em Paris. Num comentário à posteriori que Lévi-Strauss fez sobre a exposição das peças recolhidas durante a primeira expedição na galeria Wildenstein em Paris, alega que: Era uma boa coleção etnológica-posso diz̨ế-
lo agora, que tenho termos de comparação.
Tínhamos recolbido entre os cadiveu cerâmi-
cas decoradas e peles pintadas com motivos
singulares que só existem na América. Os
objetos bororo eram principalmente enfeites
de pluma, dentes e unhas de animais, pois os de pluma, dentes e unbas de animais, pois or 
bororo decoravam ricamente até suas armas de casa e utensilios. Havia peças espetaculares (Lévi-Strauss 1988: 33) ${ }^{33}$.

Nesta descrição destaca-se a onipresença dos comentários relativos à estética. Sabe-se que as peças da segunda exposição foram cuidadosamente inventariadas pelo etnólogo, que afirma: "Eu precisava instalar as minhas coleções no Museu do Homem, fazer uma ficha para cada objeto, o que significava um trabalho longo e minucioso." (LéviStrauss 1988: 37). Sobressai, portanto, a preocupação do etnólogo quanto ao conhecimento veiculado por estes objetos. Foi no exílio nos Estados Unidos da América durante a Segunda Guerra Mundial que teve a oportunidade de cultivar o interesse por peças de "arte primitiva”; e neste período criou amizade com vários artistas surrealistas, com quem partilhou o interesse. Citando o autor, "Marx Ernst era apaixonado por arte primitiva e tinha descoberto na Terceira Avenida - bem diferente do que é hoje - um pequeno antiquário alemão, que lhe vendeu um objeto indígena. Naquela época, este tipo de objeto não existia no comércio." (Lévi-Strauss \& Eribon 1988: 47). No que toca às consequências do encontro entre os artistas surrealistas e o etnólogo, ambos colecionadores de "arte primitiva, destaca-se a relação da ciência com a arte: "The encounter between Breton and Lévi-Strauss at the beginning of the war marked one of the high points in the dialogue on tribal art between avantgarde and ethnologists." ${ }^{34}$ (Massonet 2007: 108). Uma entrevista a Claude Lévi-Strauss conduzida por Monique Barbier-Mueller é bom pretexto para observar as relações do etnólogo com os objetos de arte. Destaco o paradoxo que pode constituir esta situação, onde a colecionadora entrevista o etnólogo com a intenção de compreender a sua visão sobre objetos de "arte primitiva", que para ela são sobretudo manifestações artísticas. Repara-se que, apesar de Claude Lévi-Strauss ter colecionado peças de arte, o seu interesse sempre se situou no conhecimento que o objeto lhe poderia fornecer. As peças dos índios norte-americanos que adquiriu serviram-lhe como suporte à sua análise sobre os mitos. Em relação às peças brasileiras enquanto objetos artísticos, o autor expressa-se assim:

They were authentic objects, some of which were beautiful... I was always amazed to notice how their most functional objects had aesthetic qualities. This said, while one can certainly admire the way in which an arrow's fight feather is fixed on the shaft, it does not necessarily make it an object to be placed bebind glass. ${ }^{35}$ (Barbier-Mueller 2002: 39).

Lembro que os três exemplos de grandes admiradores de peças pré-colombianas não pretendem fornecer uma visão exaustiva sobre o tipo de arte colecionada. Identifico, porém, algumas concepções recorrentes, que já abordei na tentativa de caracterização da coleção de "arte primitiva". Salientem-se as ideias de irracionalidade e de originalidade assimiladas à própria denominação deste tipo de arte. A ênfase dos colecionadores sobre a percepção estética dos objetos contrasta com as posições do etnólogo, que sem negar esta componente prefere concentrar o seu interesse no conhecimento adquirido através do objeto. Por 
fim, sublinho que a ideia de abordar a figura do colecionador a par da do etnólogo se situa igualmente na tentativa de definição das características da expedição de Victor Bandeira ao Brasil. De fato, verifica-se que o protagonista da recolha das peças do presente estudo está algures a meio caminho entre um colecionador de "arte primitiva" e um etnólogo amador.

\section{A EXPEDIÇÃO DE VICTOR BANDEIRA AO MARAJÓ}

Com o objetivo de reunir a maior quantidade de informações possíveis acerca da recolha de Victor Bandeira na ilha do Marajó, ${ }^{36}$ decidi entrar diretamente em contato com o coletor das peças. Pareceu-me importante obter dados relativos à ida de Victor Bandeira ao Marajó, à sua estadia na ilha, à escavação que realizou, assim como ao transporte dos objetos da ilha até à capital portuguesa. $\mathrm{Na}$ perspectiva de análise desta recolha à luz da questão do colecionismo, tentei igualmente obter informações sobre a escolha das peças para o Museu; o ponto de vista do colecionador sobre os objetos de arte.

Victor Bandeira, que tem hoje 78 anos, qualifica a estadia que realizou no Brasil, nos anos 1960, de "experiência inesquecível" e descreve as pessoas que descobriu no "Brasil profundo" desta forma: "aquelas pessoas que se encontram que parece que saem de livros, de romances de Jorge Amado". Confessa que até sonhou em permanecer no Brasil: "Estava a pensar que ia para o Marajó, criar gados e não sei quantos."
Também não deixa de relembrar sua vivência junto dos índios: "Realmente é viver noutro mundo, completamente diferente. A experiência de entrar numa maloca, é como quase entrar numa igreja, é uma coisa extraordinária. É uma loucura, é lindo."

Foi através de uma bolsa brasileira do Itamaraty que Victor Bandeira obteve ajuda financeira para realizar a sua expedição na Amazônia e constituir a coleção marajoara para o Museu Nacional de Etnologia. $\mathrm{Na}$ verdade, esta bolsa cobriu somente os gastos de viagens, mas foi muito útil, no sentido de facilitar suas relações com as alfândegas brasileiras, o Serviço de Proteção ao Índio $(\mathrm{SPI})^{37}$ e o transporte das peças. Foi precisamente no âmbito de sua ida ao Marajó que o português descobriu a existência de familiares que desconhecia, e que lhe haveriam de facilitar a estadia: Victor Bandeira foi apresentado a um primo, que escreveu uma carta para que pudesse ser recebido por um parente que possuía uma fazenda no Marajó. Este primeiro contato ocorreu em Belém. Victor Bandeira apresentou-lhe as razões da sua vinda:

Contei-lhe que sabia da existência na ilha do Marajó de antigos cemitérios dos indios, já abandonados quando da descoberta da ilha. Queria fazerer escavações, tentar encontrar as famosas urnas funerárias, levá-las para um museu a inangurar em Portugal (Bandeira 1975).

A resposta do homem foi a seguinte: “Amanhã vá comprar pás e enxadas e alugue um teco-teco, uma avioneta, espere por mim em Marajó. Eu trato aqui de tudo com o Luizinho." Este homem 
era na verdade um fazendeiro, que possuía uma propriedade onde era possível encontrar-se um antigo cemitério. Pode considerar-se frutuoso o resultado deste encontro: "Era uma carta de autorização manuscrita e assinada pelo Luizinho, para eu poder procurar, escavar, encontrar, trazer tudo o que quisesse dentro dos limites da sua propriedade. E viver na sua casa com o seu feitor e família" (Bandeira 1975). Sabe-se que foi à filha do primeiro familiar a que me refiro que Victor Bandeira ofereceu o livro da exposição "Índios da Amazônia", onde foram exibidas as peças marajoara que recolheu, numa exposição realizada e formulada por ele próprio, no $\mathrm{Mu}-$ seu Nacional de Etnologia em 1986. Esse livro foi visto por um artesão de Soure, que se inspirou na famosa estatueta antropomórfica (AN.384), agora no Museu Nacional de Etnologia (Figura 5), e realizou cópias miniaturizadas da mesma. Victor Bandeira afirma nunca a ter visto reproduzida no Brasil antes deste acontecimento. ${ }^{38}$

A conversa com o coletor das peças permitiu-me imaginar e transcrever elementos do seu quotidiano na escavação do teso de Camutins. Victor Bandeira relata a sua vivência diária no sítio:

Eu ia a pé de manhãzinha, ficava por lá a trabalhar até por volta do meio-dia uma hora da tarde, depois ia comer lá nessa barraquinha do gajo. Chovia sempre torrencialmente naquela região, meio-dia, uma, era fatal. Parece que ia acabar o mundo. Dai dava para ir outra vez e ficava mais umas horas naquela cena, depois voltava para o sitio onde ficava que era uma casa onde moravam uns peões, aquelas casas de madeira, onde morava mais uma familia ou duas e eu tinha um quarto lá.

Victor Bandeira lembra que esta cabana ficava a mais ou menos uma hora a cavalo do sítio. Recorda que chovia sempre no caminho de regresso, chegava encharcado a casa e de manhã vestia a roupa da véspera, ainda molhada. $\mathrm{O}$ sítio escavado é descrito nestes termos:

Tinha de se andar a cavalo até lá chegar, o sitio ficava perto de um descampado. É quase da altura desta casa (referia-se à sua própria morada, lugar onde ocorreu a entrevista) se não me engano e com uns 20 m pelo menos e desta largura talvez (estendeu os braços para ilustrar a dimensão).

Nos catálogos expositivos que referem as peças marajoara desta expedição encontrei o teso de Camutins descrito como sítio descoberto por Victor Bandeira, muito embora saiba que este sítio tinha sido intervencionado anteriormente em diversas ocasiões. Tentei, portanto, confirmar estes dados com o colecionador, que coloca esta eventualidade: "Talvez já tivesse sido escavado antes por uns americanos. Tenho uma ideia qualquer de ter lido qualquer coisa sobre isso, mas não posso jurar. Parecia uma cena absolutamente virgem. Devia ter sido há muitos anos se calhar." Victor Bandeira descreve que só vivia por perto um homem numa cabana e lembra que ele tinha uma "igaçaba" enorme onde armazenava água. Esta prática ocorre até nos dias de hoje entre os moradores da ilha.

O transporte das peças parece destacarse como a operação mais complicada dentre as diversas fases da expedição. É 
através da lembrança da famosa estatueta antropomórfica do Museu que Victor Bandeira evoca as graves consequências do transporte sobre os objetos: "Esta peça está impecável. Já com as urnas aconteceram coisas horrorosas." O coletor relata que saía da escavação à noite e reencontrava as peças todas partidas pela manhã seguinte, devido à chuva. Observa que não estava tudo intato quando realizou a escavação, com exceção das grandes urnas: "Partiu-se quase tudo, partiram-se muitas coisas." Para transportar as peças foi necessário esperar que voltasse a estação das chuvas, para poder chegar um barco até o sítio da escavação. As peças ficaram à espera numa cabana. Foi necessário arranjar madeira em Belém para fabricar caixas de transporte e depois palha, para assentar o material. As peças foram transportadas por canoas até ao porto de Belém e Victor Bandeira ainda se lembra que havia tanta água que durante a travessia, as peças dentro da embarcação batiam nos troncos de árvores da floresta inundada. As peças permaneceram um dia num matadouro e quando foram recuperadas notouse a presença de imensas "formigas fogo" (Wasmannia auropunctata) dentro das caixas, o que obrigou a utilização de produtos para as eliminar. Quando as peças chegaram a Lisboa, o colecionador viu-as a ser descarregadas. Ainda recorda este momento e a forma como algumas caixas começaram a abrir por baixo com o peso dos objetos. Quando foram abertas em Portugal ainda saíam formigas e reconheceram-se peças partidas. Descreve o momento desta forma: "parecia um filme", concluindo: "é uma saga".

Pelo fato de Victor Bandeira ter realizado uma escavação (embora de caráter pouco científico) no Marajó, interessame bastante entender a sua relação com a prática da arqueologia. Foi nesses termos que descreveu o seu interesse:

\section{Há muitos anos, fir um curso de iniciação à arqueologia que havia cá em Lisboa com um senhor que era arqueólogo. Chamava-se, se não me engano, Coronel Afonso do Paco ${ }^{39}$ e fizemos algumas escavações pelos lados de Cascais on Oeiras, já não me lembro. Tinha um gosto muito grande por isso. Teria sido a minha primeira profissão se tivesse escolbido ter uma profissão.}

Em relação à metodologia utilizada durante a escavação, sabe-se que Victor Bandeira anotava informações sobre as peças que se encontravam dentro das urnas, pois durante o processo de transporte o espólio osteológico e os objetos encontrados no interior das urnas foram separados. Porém, a recolha foi claramente destituída de qualquer método científico, como lembra Bandeira: "Gráficos e escalas e coisas e dividir aquilo nem pensar, era uma pá e uma catana e mais nada." Explica desta forma a escolha das peças que recolheu: "Tinha de ser peças para o Museu que representasse uma arte que desapareceu." O coletor explica que trouxe quase tudo o que encontrou e que achava que tinha alguma qualidade. Nota-se, portanto, o fato de ter decidido não trazer peças sem decoração. Finalmente, e segundo Victor Bandeira, todos os objetos provenientes da expedição na Amazônia foram vendidos ao Museu, exceto uma máscara proveniente dos índios do Xin- 
gu, que se encontra atualmente exposta na sua sala de estar ${ }^{40}$.

$\mathrm{Na}$ tentativa de compreender melhor a relação de Victor Bandeira com os objetos que recolheu, interroguei-o sobre o conhecimento que tinha dessas culturas antes da expedição. Victor Bandeira explica que já se interessava pela cultura marajoara antes de partir para o Brasil. Possuía, aliás, muitos livros sobre o Brasil e lembra-se ainda de um livro de uma autora chamada Heloísa ${ }^{41}$. Suponho que possa tratar-se de um livro publicado por Heloísa Alberto Torres (1895-1977), onde a autora apresentou estudos sobre cerâmicas do Marajó e arte dos índios (1940). Em relação a seu interesse pela cultura marajoara, afirma ainda: "As peças Marajó sempre me tinham interessado bastante, quando as via as achava tão diferente de tudo." Em relação à percepção das peças enquanto objetos de arte, questionei o colecionador sobre os aspectos que considera mais importantes. Quanto ao conceito de "emoção estética", afirma: "A primeira é essa e a segunda é a autenticidade do objeto." Insisti no fato de se tratar de arte funerária, no sentido de tentar encontrar a especificidade que pode ter essa coleção para Victor Bandeira: "É um mundo completamente diferente, é um mundo para mim dos mortos mas mais morto também." Explica precisamente o que procura nos objetos que recolheu:

É (a autenticidade) uma condição básica para mim. Em princípio nunca fico com uma peça que tenha sido feita para mim, que seja feita para turistas on coisa assim. Ando à procura de uma peça que em princípio já serviu para alguém e que tinha uma qualidade mesmo, e que além disso é um objeto de arte, ou que tenha qualquer coisa que a diferencia de todas as outras que são iguais.

Dever-se-ão lembrar aqui as características evocadas na tentativa de definição da coleção de "arte primitiva", entre as quais volto a constatar três elementos fundamentais e interligados: a emoção estética, a autenticidade do objeto e a condição do seu uso no passado. Questionado o colecionador sobre se teria uma peça preferida neste conjunto, foi quase espontaneamente que mencionou a famosa estatueta antropomórfica (Figura 5) que se encontra no Museu Nacional de Etnologia e constitui exemplar único. Verifico assim que a raridade é um dos elementos que a valoriza tanto aos olhos de Victor Bandeira, que a descreve desta forma:
Aquela figura. Todas as outras já tinha visto. Encontrar aquela foi o top, para mim foi. Não quer dizer que a acho uma grande escultura, mas essa é das tais peças que para mim tem a qualidade por o que elas são, porque elas representam a parte da escultura. Porque é bastante fruste digamos. É uma peça de arqueologia que nunca vi nenhuma e nem voltei a ver. Ela tem toda a cena marajoara porque tem a forma, tem a pintura, tem a escultura, tem tudo em uma peça só. Só falta falar e dizer para que serve!

Graças à colaboração do principal protagonista da expedição ao Marajó, foram obtidas informações que permitem uma melhor contextualização das peças do conjunto marajoara do MNE. Primeiro, o panorama geográfico da ilha permite compreender como a atividade arqueológica nesta região está dependente das 
duas estações anuais, sendo quase impossível realizar escavações durante o período chuvoso e transportar peças durante o período da seca. É possível supor que o fato de a escavação ter ocorrido no período das chuvas, o que por consequência acarretou a degradação de certas peças, se deve à inexperiência do colecionador. Sublinho o caráter pouco científico da recolha, que consistiu aparentemente na abertura de "buracos" com a ajuda de algumas ferramentas rudimentares, levando assim à perda de quase toda a informação contextual e da estratigrafia do sítio.

Lembro que Victor Bandeira aponta como referência Afonso do Paço, um arqueólogo particularmente influente nos meados do século XX cujos métodos eram, naturalmente, os da sua época. Pode-se questionar até que ponto esta experiência teria influenciado sua própria metodologia nas escavações no Marajó. Relativamente à escolha das peças, tive a confirmação do caráter arbitrário da recolha dos objetos marajoara. Sabe-se que as urnas funerárias constituíram uma prioridade na escolha do colecionador e de fato a sua presença destaca-se no Museu. Foram escolhidos os fragmentos de maneira intencional quando exibiam técnicas decorativas que Victor Bandeira considerou possuírem qualidade. Deste modo compreende-se que a quase ausência de peças não decoradas no conjunto se relaciona com os critérios da escolha. Noutro sentido, o périplo do transporte afetou muito o estado de conservação da maioria das peças, de onde se destacam as urnas, já deterioradas pela umidade da estação chuvosa. Ressalto assim o fato de os objetos constituírem apenas uma amostra da cultura material de povos marajoara, enquanto parte de um ritual funerário. A experiência de Victor Bandeira pode talvez transmitir reminiscências de exploradores do passado, mas prefiro considerá-la como acontecimento do seu tempo - os anos 60 do século XX.
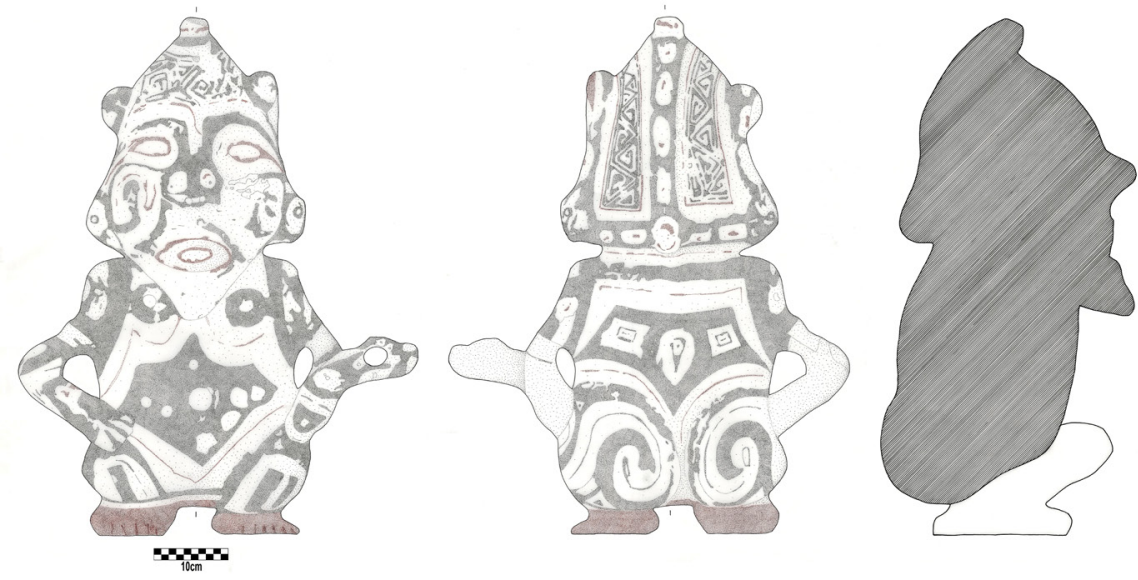

Figura 5- Estatueta antropomórfica marajoara Joanes Pintado (AN.384). 


\section{CONCLUSÃO}

Esta análise contribui para mostrar a possibilidade de explorar uma coleção museológica bem além da realidade material dos objetos que a compõem. Assim, é possível abrir o estudo arqueológico para outros campos como são os da História da Arte, da Museologia e até, talvez, da Psicologia. Na tentativa de entrar na mente do colecionador de peças americanas procurei entender a especificidade que têm as coleções, nomeadamente na relação que fundamentam entre o seu protagonista e o passado.

Destaquei o conceito de emoção estética manifestado por Victor Bandeira frente a esses objetos, que apesar de serem considerados frustres do ponto de vista artístico (recorde-se que se trata da mesma opinião manifestada por Dora Janssen) estimulam de maneira inconsciente o imaginário do colecionador. Imagino que a oportunidade de realizar uma escavação na perspectiva de recolher objetos para constituir uma coleção seja, do ponto de vista da autenticidade, uma situação perfeita para o colecionador. Além disso, o fato de tratar-se de arte funerária reforça a relação ao tempo pretérito e torna o objeto mediador quase místico entre visível e invisível. Victor Bandeira qualifica os dois aspectos desta forma: o "mundo dos mortos" e o "mundo morto", o primeiro encarnado pelo teso cerimonial onde ocorreu um ritual funerário acompanhado do depósito de corpos e oferendas e o segundo como evocação de uma cultura desaparecida.

E aproveito para regressar a um reconhecido admirador de arte pré-colombiana:
As divindades artecas associadas, na nossa memória, a templos cem vezues mais fotografados, às cerâmicas peruanas tantas vezes mostradas, são essas as paisagens que nos confortam. Esta é a razão pela qual as excluo do meu discurso, apontando antes para o que é surpreendente, incomum, desconcertante, (a meu ver) maravilhoso: a cerâmica amazônica! (Barbier 1995: 6).

\section{AGRADECIMENTOS}

Minha investigação de mestrado, da qual este artigo resulta, não poderia ter sido levada a bom termo sem o apoio da Prof ${ }^{\text {a }}$. Dra. Rosa Varela Gomes, que orientou o trabalho. Devo um voto de especial agradecimento a Victor Bandeira, pelo seu precioso testemunho, pelos relatos da expedição que partilhou comigo e pela inspiração que me transmitiu. Agradeço também à Prof ${ }^{a}$ Dra. Denise P. Schaan pelo seu estímulo, à Prof ${ }^{a}$. Dra. Marcia Bezerra, assim como ao Dr. Rui Gomes Coelho, a Profa . Dra. Francisca Alves Cardoso e a Dra . Auriane Kerbrat pela leitura crítica do trabalho e pelas sugestões feitas.

\section{NOTAS}

${ }^{1}$ Foram realizadas seis exposições em Portugal com catálogos publicados onde se encontraram algumas peças deste conjunto. Vejam-se: Novais 1966; Oliveira 1972; Oliveira 1986; Paulino 1991; Coelho, Costa \& Koch 1994; Brito 2000.

2 Intitula-se "Testemunhos funerários da ilha do Marajó no Museu Dr. Santos Rocha e no Museu Nacional de Etnologia - interpretação arqueológica", orientada pela Prof ${ }^{a}$ Dra. Rosa Varela Gomes, e apresentada em 14/02/2011 à Faculdade de Ciências Sociais e Humanas da Universidade Nova de Lisboa (Portugal). 
${ }^{3} \mathrm{O}$ termo "coleções domésticas" é utilizado por Bezerra em um artigo onde a autora revaloriza este tipo de colecções defendendo que, ao contrário das coleções formadas por "grandes colecionadores" não constituem uma ameaça ao património arqueológico. As "coleções domésticas" podem ser vistas como testemunho da relação entre as pessoas e as coisas do passado no presente (Bezerra 2011).

${ }^{4}$ Nos catálogos de exposição o teso escavado é descrito como situado na região do lago Arari (Oliveira 1972), embora seja geograficamente mais próximo do rio Anajás.

${ }^{5}$ Este termo corresponde à denominação regional do artefato na ilha do Marajó.

${ }^{6}$ A fase Marajoara destaca-se na cronologia das culturas arqueológicas da ilha do Marajó por constituir um período de mudança caracterizado por complexificações de ordem social e tecnológica. Denise Schaan divide esta fase em quatro períodos: incipiente (70 a.C. a 400), expansionista (400 a 700), clássico (700 a 1100) e declínio (1100 a 1300) (Schaan 2004).

7 Também encontramos escrito o termo "kamayura". Aproveito para mencionar que Françoise Bandeira é autora de um artigo sobre os kamaiurá publicado em 1966.

${ }^{8} \mathrm{O}$ Teso de Camutins foi visitado e/ou escavado durante o século XIX por vários cientistas como Orville Derby, Ladislau Netto e William Farabee. Nos anos 40 do século XX foi escavado pelos americanos Betty Meggers e Clifford Evans e no início do século XXI foi pesquisado por Denise Schaan no âmbito de sua tese de doutorado (Schaan 2004).

${ }^{9}$ Designa um dos estilos elaborados por Meggers e Evans (1957) para classificar a cerâmica da fase Marajoara. É considerado um dos mais emblemáticos desta fase arqueológica e corresponde ao tratamento de pintura ver- melha e/ou preta sobre engobo claro.

${ }^{10}$ Outro estilo da classificação de Meggers e Evans (1957), que se caracteriza por um tratamento com engobo vermelho em peças que podem possuir ondulações no bordo ou decoração modelada.

${ }^{11}$ Mais um estilo da classificação de Meggers e Evans (1957), caracterizado por um tratamento de excisão sobre engobo vermelho.

${ }^{12}$ Para uma breve apresentação das "Galerias da Amazônia”, consultar Porfiro 2005. Para uma descrição detalhada da constituição da coleção Wauja, consulte-se Neto 2004.

13 Todas as traduções de citações são da minha responsabilidade.

“O antiquário é atraído por tudo o que é antigo; classifica os objetos e os monumentos seguindo regras tão antigas quanto mal definidas: per genus proximum et differentiam specificam ("pelo tipo mais próximo e a diferença mais notável'); o arqueólogo quer constituir o mundo dos objetos em sistemas, alarga o conceito de monumentos (que foram fabricados ou edificados para monere, 'avisar') ao de traços, restos por vezes ínfimos que resultam da actividade inconsciente dos homens do passado."

${ }^{14}$ A utilização desta designação justifica-se, a meu ver, apenas por ser usada pelos colecionadores, sendo testemunha da sua visão estetizante sobre os objectos não ocidentais. Aponto porém o seu caráter controverso, na medida em que se trata de uma designação carregada de preconceitos etnocêntricos que hierarquiza as produções não ocidentais numa visão evolucionista das culturas. Esta ideia foi aliás muito bem ilustrada na altura da escolha de um nome para designar o Musée du Quai Branly, em Paris, sendo a proposta de "Musée des Arts Premiers" associada a estes mesmos problemas. Para mais informações sobre este tema, consultar Bethencourt 2003. 
15 "Não é por ser belo que o objeto faz sonhar e ver o mundo de maneira diferente, é por fazer sonhar e ver o mundo de maneira diferente que é belo."

16 "Por vezes, acabo por uni-lo a mim e vejo-o como um testemunho arqueológico de mim mesmo."

${ }^{17}$ É por exemplo o caso de Sigmund Freud (1856-1939), que além de ser considerado o pai da psicanálise foi também grande colecionador de antiguidades. Note-se, aliás, que possuía algumas peças arqueológicas pré-colombianas (Vieville \& Garnier 2008). Existe um estudo biográfico sobre Freud enquanto colecionador de peças arqueológicas e de arte em Burke 2006.

18 "Queria constituir conjuntos coerentes de certas regiões ou centros estilísticos."

19 "Um conjunto pouco habitual de cerâmicas da ilha brasileira do Marajó."

${ }^{20}$ Esta temática está ilustrada em dois artigos da imprensa que referem controvérsias surgidas em relação à coleção pré-colombiana de Jean-Paul Barbier-Mueller: Sukman 2002; Roux \& Stroobants 2006.

21 "Assenta em critérios estéticos, assenta em paixões". Esta citação foi retirada de uma entrevista feita a Dora Janssen na altura da exposição, e encontra-se em Duplat 2006.

22 Os chimus correspondem à cultura précolombiana que se desenvolveu na costa Norte do Peru a partir do ano 1000 e que tinha como capital do seu poderoso reino a cidade de Chan Chan. Esta cultura destacase pelo seu trabalho metalúrgico, do qual menciono como exemplo a técnica da martelagem sobre folhas de ouro na realização de máscaras mortuárias. Sobre a metalurgia desenvolvida pelas culturas andinas antigas, veja-se Lévine 2000.

23 “"Tenho acumulado mais de 500 obras sobre a arte pré-colombiana." Esta citação foi retirada de uma entrevista feita a Dora Janssen, na altura da exposição e encontra-se em Duplat 2006.

24 "Enquanto nos pré-colombianos as linhas são mais impuras e também pode haver coisas muito feias, há tanta expressão e estranheza nesta arte que produz uma simbiose com a natureza. Nela encontramos uma religiosidade. Os objectos esculpidos estão ligados à natureza, ao sol, ao jaguar." Esta citação foi retirada de uma entrevista feita a Dora Janssen na altura da exposição "Les Maitres de l'Art Précolombien" e encontrase em Duplat, 2006. O itálico é meu

25 "Elas têm uma outra dimensão oculta. Para mim, são receptáculos de mistérios, os dos povos que viviam em simbiose com a natureza. Convidam-me à arte de contemplar e de sonhar." A citação encontra-se em Le Fort 2005. O itálico é meu.

${ }^{26}$ No âmbito de um trabalho sobre a percepção da natureza na Amazónia, o autor realiza várias entrevistas entre as populações da Amazónia brasileira. Cito uma das conclusões que é tirada do estudo, relacionada com a visão que populações actuais têm sobre o território onde vivem: "Apesar das grandes transformações ocorridas nos contextos sociais e econômicos do Brasil e em toda a área correspondente à chamada Amazônia brasileira no decorrer dos últimos cinco séculos, a natureza constitui o elemento central e organizador das representações sobre a região" (Bueno 2008: 81).

27 “Estava obcecado pela verdade, por uma visão que era a de uma coleção constituída por "objectos de sonho"."

28 “Só são importantes as obras que ficam e vêm passar os colecionadores."

${ }^{29} \mathrm{O}$ itálico é meu.

${ }^{30}$ É possível visualizar esta peça em Barry \& Corrêa 2007:9. 
31 "Criaram uma coleção destituída de qualquer preconceito etnográfico; é composta cuidadosamente por uma amostra do passado da América, sobressai pela qualidade estética e pela originalidade dos seus objetos."

32 "Criar uma obra de arte feita das obras dos outros porque eu não tinha nenhum dos dons que possuem os verdadeiros criadores".

${ }^{33}$ Há um trabalho interessante sobre expedições e constituição de coleções etnográficas no Brasil que contém também informações sobre as expedições realizadas por Claude e Dina Lévi-Strauss: Grupioni 1998. $\mathrm{O}$ destaque é meu.

34 “ $\mathrm{O}$ encontro entre Breton e Claude LéviStrauss no início da guerra resultou num dos pontos mais importantes do diálogo da arte tribal com a avant-garde e os etnólogos."

35 "Eram objetos autênticos, alguns dos quais lindíssimos... Estava sempre surpreendido por notar como os objectos mais funcionais podiam possuir qualidades estéticas. Porém, podemos admirar a maneira como a pena de um arco é fixada no seu eixo sem que isso faça necessariamente dele um objeto para ser colocado numa vitrina." O destaque é meu.

${ }^{36}$ Foi realizada uma entrevista em casa do antiquário em Costa da Caparica (Almada, Portugal), no dia 8 de janeiro de 2010, às 16 horas, tendo durado cerca de uma hora. Existe um registo fotográfico da expedição ao Marajó que Victor Bandeira depositou no Museu Nacional de Etnologia. São seis fotografias, na sua totalidade, sendo algumas delas pertinentes para a minha análise. Não foi autorizada, porém, a sua publicação. A única imagem publicada (Oliveira 1986) regista Victor Bandeira segurando uma conhecida estatueta antropomórfica (AN.384). Em todo o caso, descreverei sucintamente o conteúdo das restantes fotografias: 1: Armação de um cavalo com Victor Bandeira e três companheiros, 2: Françoise Carel Bandeira junto à escavação e a estatu- eta antropomórfica (AN.384), 3: Françoise Carel-Bandeira montada num cavalo, 4: Françoise Carel-Bandeira e a armação de um cavalo por dois homens, 5: Françoise Carel-Bandeira e dois companheiros ao lado da escavação, com a estatueta antropomórfica (AN.384).

${ }^{37}$ Trata-se da atual Fundação Nacional do Índio (FUNAI).

${ }^{38}$ Esta informação encontra-se em Brito 2000.

${ }^{39}$ Foi nos anos de 1930 que o coronel Afonso do Paço (1895-1968) começou a desenvolver interesse por arqueologia e etnografia Efetuou várias explorações arqueológicas, nomeadamente no Castro da Vila Nova de S. Pedro, juntamente com o Padre E. Jalhay (Almeida 1980).

${ }^{40}$ Assinalo que esta informação foi contradita, informalmente, pelos funcionários do Museu Nacional de Etnologia, assim como por pesquisadores da Faculdade de Ciências Sociais e Humanas da Universidade Nova de Lisboa.

${ }^{41}$ Victor Bandeira afirma ter depositado seus livros no Museu Nacional de Etnologia, porém não encontrei registros permitindo a identificação dos mesmos na atual biblioteca.

\section{REFERÊNCIAS}

Almeida, F. de. 1980. Elogio do Ten.-Cor. Afonso do Paço. Lisboa: Academia Portuguesa de História.

Bandeira, F. 1966. Chez les indiens Kamayura du Alto Xingu. Geographica 2(5):3-18.

Bandeira, V. 1975. A Bênção, seu coronel! $A$ Capital. Lisboa.

Barbier, J.P. 1995. Arte pré-colombiana da colecção Barbier-Mueller. Lisboa: Fundação Calouste Gulbenkian. 
Barbier-Mueller, J.P. e R. Enthoven. 2003. Rêves de collection: Sept millénaires de sculptures inédites: Europe, Asie, Afrique. Paris: Somogy Genève: Musée Barbier-Mueller.

Barbier-Mueller, M. 2002. Interview with Claude Lévi-Strauss. Arts et Cultures 3: 37-43.

Barry, I. e C. G. Corrêa. 2007. Amazonia. Brasil prehistórico. Barcelona: Museu BarbierMueller art precolombí.

Baudrillard, J. 2004. O sistema dos objetos. São Paulo: Perspectiva.

Benjamin, W. 2000. Je déballe ma bibliothèque. Paris: Éditions Payot \& Rivages.

Bethencourt, F. Editor. 2003. Arquivos do Centro Cultural Calouste Gulbenkian (2003). Volume XLV: les Arts Premiers. Lisboa-Paris: Fundação Calouste Gulbenkian.

Bezerra, M. 2011. "As moedas dos índios": um estudo de caso sobre os significados do patrimônio arqueológico para os moradores da Vila de Joanes, ilha de Marajó, Brasil. Boletim do Museu Paraense Emílio Goeldi. Ciências Humanas v. 6. n. 1. jan.-abr.: 57-70.

Brito, J. P. de. 2000. Os índios, Nós. Lisboa: Museu Nacional de Etnologia.

Bueno, M. F. 2008. Natureza como representação da Amazônia. Espaço e Cultura 23: 77-86.

Burke, J. 2006. The Gods of Freud: Sigmund Freud's art collection. Australia: Random House.

Casas, A. 2004. In the heart of Barcelona: The Barbier-Mueller Museum of Pre-Columbian Art. Arts et Cultures 5: 93-99.

Coelho, R. G. de A., F. J. da Costa e A. Koch. 1994. Memória da Amazônia. Etnicidade e territorialidade. Porto: Fundação Gomes Teixeira.

Derlon, B., e M. Jeudy-Ballini. 2008. La passion de l'art primitif: Enquête sur les collection- neurs. Paris: Gallimard.

Grupioni, L. D. B. 1998. Coleções e expedições vigiadas, os etnólogos no conselho de fiscalizaçãa das expedições artísticas e científicas no Brasil. São Paulo: Editora Hucitec/Anpocs.

Le Fort, G. 2005. Maîtres des Amériques: Hommage aux artistes précolombiens: La collection Dora et Paul Janssen. Milan: 5 continents. Bruxelles: Fonds Mercator.

Lévine, D. 2000. L'or des dieux, l'or des Andes, Pérou-Equateur-Colombie. Metz: Editions Serpenoise.

Lévi-Strauss, C. e D. Eribon. 1988. De près et de loin. Paris: Editions Odile Jacob.

Massonet, S. 2007. Collecting tribal art: André Breton \& Claude Lévi-Strauss. Tribal art 46: 100-111.

Meggers, B. e C. Evans. 1957. Archaeological investigations at the Mouth of the Amazon, Washington: U.S. Govt. Print. Off.

Musée Barbier-Mueller. Editor. 1987. Hier, aujourd'bui, demain: regards sur les collections et sur les activités du Musée Barbier-Mueller. Genève: Le Musée Barbier-Mueller. Neto, A. B. 2004. Com os indios Wanja: objectos e personagens de uma colecção amazônica. Lisboa: Museu Nacional de Etnologia.

Newton, D., H. Waterfield, e J.P. Barbier. 1995. Sculpture: Chefs-d'oeuvre du Musée Barbier-Mueller. Paris: Impr. Nationale.

Novais, M. 1966. Arte do indio brasileiro. Lisboa: Fundação Calouste Gulbenkian.

Oliveira, E. Veiga de. e J. F. Branco 1986. Índios da Amazônia. Lisboa: Museu de Etnologia do Instituto de Investigação Científica Tropical.

Oliveira, E. V. de. 1972. Exposição povos e culturas no Museu de Etnologia do Ultramar. Lisboa: 
Museu de Etnologia do Ultramar.

Paulino, F. F. 1991. Brasil nas vésperas do mundo moderno. Lisboa: Comissão Nacional para as Comemorações dos Descobrimentos Portugueses.

Pomian, K. 1987. Collectionneurs, amateurs et curieux. Paris, Venise: XVI-XVIIIe siècle. Paris: Gallimard.

Porfírio, J.L. 11 de Fevereiro de 2005. Ao contrário da exposição. Expresso: 36. Lisboa.

Pratas, F. 2000. Victor Bandeira. Ícon (parte integrante da edição n ${ }^{\circ} 624$ do jornal "O Independente"). Abril: 37-44.

Roux, E. e J.P. Stroobants. Bruxelles correspondant. 10 de Outubro de 2006. La vigilance du serpent à plumes. Le Monde. Paris.

Schaan, D. P. 2004. The Camutins chiefdom: Rise and development of social complexity on Marajó Island, Brazilian Amazon. Tese de Doutorado, Departamento de Antropologia, Universidade de Pittsburgh, EUA.

2006. Manejo ecológico e o desenvolvimento de sociedades complexas na ilha de Marajó, Brasil, in Pueblos y paisajes antiguos de la selva amaźónica. Editado por G. MorcoteRios, S. Mora-Carmago e C. Franky-Calvo, pp.348-365. Taraxacum: Bogotá.

Sukman, H. (23 de Junho de 2002). Isso é coisa de índio! O Globo. Rio de Janeiro.

Torres, H. A. 1940. Arte indígena da Amazốnia. Rio de Janeiro: Imprensa Nacional; Publicações do Serviço do Patrimônio Histórico e Artístico Nacional.

Troufflard, J. 2011. Testemunhos funerários da ilha do Marajó no Museu Dr. Santos Rocha e no Museu Nacional de Etnologia - interpretação arqueológica. Tese de Mestrado. Faculdade de Ciências Sociais e
Humanas da Universidade Nova de Lisboa, Portugal.

Viéville, D. e B. Garnier. 2008. Rodin-Freud, colectionneurs. La passion à l'oeuvre. Paris: Nicolas Chaudun/ Musée Rodin.

Recebido em 18/05/2011.

Aprovado em 30/07/2011. 